\title{
Dimensional and Chemical Control of Colossal Magnetoresistance in New Manganites
}

\author{
Ru-Shi Liu ${ }^{*}$, Chih-Hung Shen, Shu-Fen Hu, Jauyn Grace Lin and Chao-Yuan Huang \\ Department of Chemistry, National Taiwan University, Taipei, Taiwan, R.O.C. \\ National Nano Device Laboratories, Hsinchu, Taiwan, R.O.C. \\ Center for Condensed Matter Sciences, National Taiwan University, Taipei, Taiwan, R.O.C. \\ Center for Condensed Matter Sciences, Department of Physics and Department of Electrical Engineering, National Taiwan University, \\ Taipei, Taiwan, R.O.C.
}

The effects of structural, electrical and magnetic properties with the isovalent chemical substitution of $\mathrm{Ca}^{2+}$ into the $\mathrm{Sr}^{2+}$ sites in new series of two-dimensional $\mathrm{La}_{1.2}\left(\mathrm{Sr}_{1.8-\mathrm{x}} \mathrm{Ca}_{\mathrm{x}}\right) \mathrm{Mn}_{2} \mathrm{O}_{7}$ compounds $(\mathrm{x}=0 \sim 0.8)$ and three-dimensional $\mathrm{La}_{0.6}\left(\mathrm{Sr}_{0.4-\mathrm{x}} \mathrm{Ca}_{\mathrm{x}}\right) \mathrm{MnO}_{3}$ compounds $(\mathrm{x}$ $=0 \sim 0.4)$ are investigated. The Curie temperatures $\left(\mathrm{T}_{C}\right)$ decreased from $135 \mathrm{~K}$ to $102 \mathrm{~K}$ and $370 \mathrm{~K}$ to $270 \mathrm{~K}$ for $\mathrm{x}=0$ to 0.4 in $\mathrm{La}_{1.2}\left(\mathrm{Sr}_{1.8-\mathrm{x}} \mathrm{Ca}_{\mathrm{x}}\right) \mathrm{Mn}_{2} \mathrm{O}_{7}$ and $\mathrm{La}_{0.6}\left(\mathrm{Sr}_{0.4-\mathrm{x}} \mathrm{Ca}_{\mathrm{x}}\right) \mathrm{MnO}_{3}$, respectively. The antiferromagnetic behavior with Néel temperature around $30 \mathrm{~K}$ was found in the $x=0.8$ sample in $\mathrm{La}_{1.2}\left(\mathrm{Sr}_{1.8-\mathrm{x}} \mathrm{Ca}_{\mathrm{x}}\right) \mathrm{Mn}_{2} \mathrm{O}_{7}$. The composition induced structural variation has been found in $\mathrm{La}_{0.6}\left(\mathrm{Sr}_{0.4-\mathrm{x}} \mathrm{Ca}_{\mathrm{x}}\right) \mathrm{MnO}_{3}$. All the results demonstrate that the dimensionality and chemical size play an important role in controlling the colossal magnetoresistance in manganites.

KEYWORDS: Colossal Magnetoresistance; $\mathrm{La}_{1.2}\left(\mathrm{Sr}_{1.8-\mathrm{x}} \mathrm{Ca}_{\mathrm{x}}\right) \mathrm{Mn}_{2} \mathrm{O}_{7} ; \mathrm{La}_{0.6}\left(\mathrm{Sr}_{0.4-\mathrm{x}} \mathrm{Ca}_{\mathrm{x}}\right) \mathrm{MnO}_{3}$

\section{Introduction}

Recently, there has been revived interest in mixed valence manganese perovskites. The Ruddlesden-Popper $R_{\mathrm{n}+1} \mathrm{Mn}_{n} \mathrm{O}_{3 n+1}$ system ( $\mathrm{R}=$ rare earth) exhibits a colossal magnetoresistance (CMR) in a relatively small temperature range around the Curie temperature $\left(\mathrm{T}_{C}{ }^{1)}\right.$. A suitable substitution of $A^{2+}$ ions for $R^{3+}$ ions results in $\mathrm{Mn}^{3+} / \mathrm{Mn}^{4+}$ mixed valency, and hence the strong coupling between the magnetic ordering and the electrical conductivity demonstrates a strong relationship between the electrical resistivity and the spin alignment which has been explained by the double-exchange mechanism ${ }^{2,3)}$.

In the $\mathrm{n}=\infty$ compounds, the gradual replacement of $\mathrm{Ca}^{2+}$ by $\mathrm{Sr}^{2+}$ in $\mathrm{La}_{0.75}\left(\mathrm{Ca}_{0.25-\mathrm{x}} \mathrm{Sr}_{\mathrm{x}}\right) \mathrm{MnO}_{3}$ results in an increase in $\mathrm{T}_{C}$ from $~$ $225 \mathrm{~K}$ of $\mathrm{x}=0$ to $\sim 340 \mathrm{~K}$ of $\mathrm{x}=0.25^{4)}$. The phase transformation from orthorhombic to rhombohedral by increasing the $\mathrm{Sr}$ content has been observed in the $\mathrm{La}_{0.75}\left(\mathrm{Ca}_{0.25-\mathrm{x}} \mathrm{Sr}_{\mathrm{x}}\right) \mathrm{MnO}_{3}$ system. However, a detailed study on the phase transformation is needed.

The compounds with the $\mathrm{n}=2$ member exhibited a conducting ferromagnet with a MR $[\rho(0) / \rho(H)]$ ratio higher than those of the $n=3$ and $n=\infty$ members. This implies that a lower dimensionality is more favorable for CMR. Many interesting studies have been carried out on the manganites with $\mathrm{La}_{1.2} \mathrm{Sr}_{1.8} \mathrm{Mn}_{2} \mathrm{O}_{7}$ compound, which is a conducting ferromagnet with a $T_{C}$ of $130 \mathrm{~K}$ and with a high MR value ${ }^{5)}$. On the other hand, the manganites $\mathrm{La}_{n-n x} \mathrm{Ca}_{1+n x} \mathrm{Mn}_{n} \mathrm{O}_{3 n+1}$ have been performed by Asano et al ${ }^{6}$. In the $\mathrm{La}_{1.2} \mathrm{Ca}_{1.8} \mathrm{Mn}_{2} \mathrm{O}_{7}$ layered compound, they have observed a ferromagnetic transition at $T_{C}=240 \mathrm{~K}$ and a higher MR ratio than those of $n=3$ and $n=\infty$ materials. Therefore, the solid solution properties between $\mathrm{Sr}^{2+}$ and $\mathrm{Ca}^{2+}$ resulting in $\mathrm{La}_{1.2}\left(\mathrm{Sr}_{1.8-\mathrm{x}} \mathrm{Ca}_{\mathrm{x}}\right) \mathrm{Mn}_{2} \mathrm{O}_{7}$ should be of interest.

In this paper, we demonstrate the structural, electrical and magnetic properties with the isovalent chemical substitution of $\mathrm{Ca}^{2+}$ into the $\mathrm{Sr}^{2+}$ sites in a series of three-dimensional $\mathrm{La}_{0.6}\left(\mathrm{Sr}_{0.4-\mathrm{x}} \mathrm{Ca}_{\mathrm{x}}\right) \mathrm{MnO}_{3}$ compounds $(x=0 \sim 0.4)$ and two-dimensional $\mathrm{La}_{1.2}\left(\mathrm{Sr}_{1.8-\mathrm{x}} \mathrm{Ca}_{\mathrm{x}}\right) \mathrm{Mn}_{2} \mathrm{O}_{7}$ compounds $(x=0 \sim 0.8)$.

\section{Experimental}

High purity powders of $\mathrm{La}_{2} \mathrm{O}_{3}, \mathrm{SrCO}_{3}, \mathrm{CaCO}_{3}$ and $\mathrm{MnO}_{2}$ were

\footnotetext{
Corresponding author: Department of Chemistry, National Taiwan University, Roosevelt Road, Section 4, Taipei, Taiwan, R.O.C.

E-mail: rsliu@ccms.ntu.edu.tw
}

weighted in appropriate proportions to obtain the nominal compositions of $\mathrm{La}_{0.6}\left(\mathrm{Sr}_{0.4-\mathrm{x}} \mathrm{Ca}_{\mathrm{x}}\right) \mathrm{MnO}_{3}(\mathrm{x}=0 \sim 0.4)$ and $\mathrm{La}_{1.2}\left(\mathrm{Sr}_{1.8-\mathrm{x}} \mathrm{Ca}_{\mathrm{x}}\right) \mathrm{Mn}_{2} \mathrm{O}_{7}(0 \leq x \leq 0.8)$ were prepared by solid state reaction. The mixtures were calcined in air for $24 \mathrm{~h}$ at $900{ }^{\circ} \mathrm{C}$ and $1200^{\circ} \mathrm{C}$, respectively. Then, the samples were sintered in air at $1400 \sim 1500{ }^{\circ} \mathrm{C}$ for $24 \mathrm{~h}$ with intermediate grinding after each heating step ${ }^{7,8)}$. X-ray powder diffraction (XRD) of samples was carried out with a SCINTAG (X1) diffractometer $(\mathrm{Cu} \mathrm{K} \alpha$ radiation, $\lambda=1.5406 \AA$ ). Magnetization data were taken from a superconducting quantum interference device (SQUID) magnetometer (Quantum Design).

\section{Results and discussion}

The powder XRD patterns of $\mathrm{La}_{0.6}\left(\mathrm{Sr}_{0.4-\mathrm{x}} \mathrm{Ca}_{\mathrm{x}}\right) \mathrm{MnO}_{3}(\mathrm{x}=0$ $0.4)$ are shown in Fig. 1. The series samples are single phase. For the samples with $\mathrm{x}=0$ and 0.4 , all the peaks in each pattern can be indexed with a rhombohedral unit cell (space group: $R-3 c$ ) and orthorhombic (space group: Pbnm), respectively. As x increases to $x=0.3$, some reflection planes merge together, which indicates that in the $x<0.3$ region the structure is orthorhombic and in the $x$ $\geq 0.3$ region the structure becomes orthorhombic. An increase in the $\mathrm{Ca}$ content leads to an increase in the distortion of the $\mathrm{MnO}_{6}$ octahedra.

In Fig. 2 we show the XRD patterns of $\mathrm{La}_{1.2}\left(\mathrm{Sr}_{1.8-\mathrm{x}} \mathrm{Ca}_{\mathrm{x}}\right) \mathrm{Mn}_{2} \mathrm{O}_{7}$ $(x=0 \sim 0.8)$, which are all single phase. The samples can be indexed with tetragonal unit cell (space group: $14 / \mathrm{mmm}$ ). In the inset of Fig. 2, we show the ideal crystal structure of ( $\mathrm{La}, \mathrm{Sr}, \mathrm{Ca})_{3} \mathrm{Mn}_{2} \mathrm{O}_{7}$ which consists of double perovskite layers, and each layer is made up of a two dimensional network of $\mathrm{MnO}_{6}$ octahedra. Along the $c$-axis, the bilayers are separated from one another by $(\mathrm{La}, \mathrm{Sr}, \mathrm{Ca})-\mathrm{O}$ layers. There are two $(\mathrm{La}, \mathrm{Sr}, \mathrm{Ca})$ sites in this crystal structure: a twelve-coordinate site between the perovskite slabs and a nine-coordinate site between rock-salt slabs.

The temperature dependence of magnetization in a magnetic field of $0.1 \mathrm{~T}$ of $\mathrm{La}_{0.6}\left(\mathrm{Sr}_{0.4-\mathrm{x}} \mathrm{Ca}_{\mathrm{x}}\right) \mathrm{MnO}_{3}(\mathrm{x}=0 \sim$ $0.4)$ and $\mathrm{La}_{1.2}\left(\mathrm{Sr}_{1.8-\mathrm{x}} \mathrm{Ca}_{\mathrm{x}}\right) \mathrm{Mn}_{2} \mathrm{O}_{7}(\mathrm{x}=0 \sim 0.8)$ were shown in Figs. 3(a) and 3(b), respectively. A systematic analysis of the paramagnetic to ferromagnetic transition temperature $\mathrm{T}_{C}$ versus the concentration of $\mathrm{Ca}^{2+}$ for $\mathrm{La}_{0.6}\left(\mathrm{Sr}_{0.4-\mathrm{x}} \mathrm{Ca}_{\mathrm{x}}\right) \mathrm{MnO}_{3}$ indicates that the $\mathrm{T}_{C}$ 's decreases as the Ca content increases [see Fig. 3(a)] ${ }^{7,8)}$. In Fig. 3(b), it indicates a sharp paramagnetic to ferromagnetic transition in $\mathrm{La}_{1.2}\left(\mathrm{Sr}_{1.8-\mathrm{x}} \mathrm{Ca}_{\mathrm{x}}\right) \mathrm{Mn}_{2} \mathrm{O}_{7}(\mathrm{x}=0 \sim 0.8)$ within the $\mathrm{T}_{C}$ 


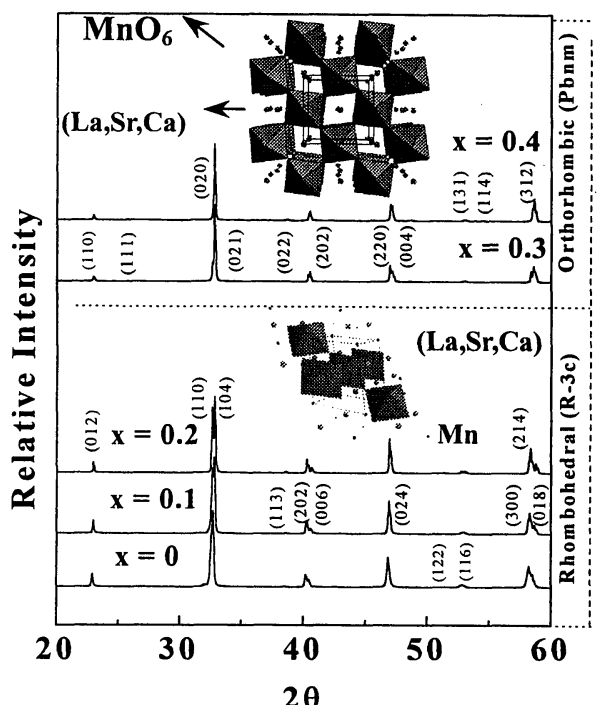

Fig. 1. XRD patterns of $\mathrm{La}_{0.6}\left(\mathrm{Sr}_{0.4-\mathrm{x}} \mathrm{Ca}_{\mathrm{x}}\right) \mathrm{MnO}_{3}$. The corresponding rhombohedral and orthorhombic structures are shown in the inset of Fig. 1.

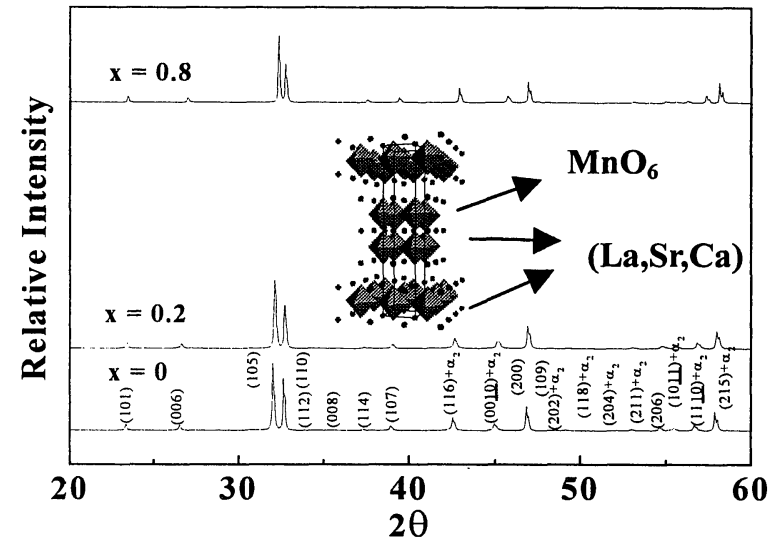

Fig. 2. XRD patterns of $\mathrm{La}_{1.2}\left(\mathrm{Sr}_{1.8-\mathrm{x}} \mathrm{Ca}_{\mathrm{x}}\right) \mathrm{Mn}_{2} \mathrm{O}_{7}$. The inset shows the crystal structure of $\mathrm{La}_{1.2}\left(\mathrm{Sr}_{1.8-\mathrm{x}} \mathrm{Ca}_{\mathrm{x}}\right) \mathrm{Mn}_{2} \mathrm{O}_{7}$.

temperature range of $135 \sim 71 \mathrm{~K}$. The antiferromagnetic behavior with Néel temperature around $30 \mathrm{~K}$ was found in the $x=0.8$ sample in $\mathrm{La}_{1.2}\left(\mathrm{Sr}_{1.8-\mathrm{x}} \mathrm{Ca}_{\mathrm{x}}\right) \mathrm{Mn}_{2} \mathrm{O}_{7}$. In Fig. 4, a decrease in $\mathrm{T}_{C}$ from $>350 \mathrm{~K}$ for $\mathrm{x}=0$ to $270 \mathrm{~K}$ for $\mathrm{x}=0.4$ in $\mathrm{La}_{0.6}\left(\mathrm{Sr}_{0.4-\mathrm{x}} \mathrm{Ca}_{\mathrm{x}}\right) \mathrm{MnO}_{3}$ and $135 \mathrm{~K}$ for $\mathrm{x}=0$ to $71 \mathrm{~K}$ for $\mathrm{x}=0.8$ in $\mathrm{La}_{1.2}\left(\mathrm{Sr}_{1.8-\mathrm{x}} \mathrm{Ca}_{\mathrm{x}}\right) \mathrm{Mn}_{2} \mathrm{O}_{7}$ were observed. It has been shown that $\mathrm{T}_{C}$ is very sensitive to chemical pressure (i.e., structural distortions induced by changing the average radius of the cations).

\section{Conclusion}

An investigation of the new series of three-dimensional $\mathrm{La}_{0.6}\left(\mathrm{Sr}_{0.4-\mathrm{x}} \mathrm{Ca}_{\mathrm{x}}\right) \mathrm{MnO}_{3}(x=0 \sim 0.4)$ and two-dimensional $\mathrm{La}_{1.2}\left(\mathrm{Sr}_{1.8-\mathrm{x}} \mathrm{Ca}_{\mathrm{x}}\right) \mathrm{Mn}_{2} \mathrm{O}_{7}(x=0 \sim 0.8)$ mangnites has allowed us to establish a relationship between the ionic size and Curie temperature.This study has demonstrated that the size of the interpolated cation by tuning the concentration between $\mathrm{Ca}^{2+}$ and $\mathrm{Sr}^{2+}$ plays a role in the controlling the magnetrotranport properities of the colossal magnetroresistance $\mathrm{La}_{n-n x}(\mathrm{Sr}, \mathrm{Ca})_{1+n x} \mathrm{Mn}_{n} \mathrm{O}_{3 n+1}$ materials.

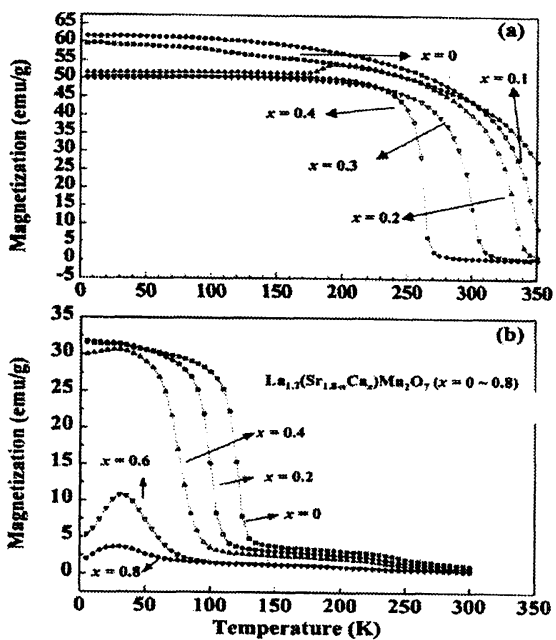

Fig. 3. Temperature dependence of magnetization at a magnetic field of $0.1 \mathrm{~T}$ for (a) $\mathrm{La}_{0.6}\left(\mathrm{Sr}_{0.4-\mathrm{x}} \mathrm{Ca}_{\mathrm{x}}\right) \mathrm{MnO}_{3}(\mathrm{x}=0 \sim 0.4)$ and (b) $\mathrm{La}_{1.2}\left(\mathrm{Sr}_{1.8-\mathrm{x}} \mathrm{Ca}_{\mathrm{x}}\right) \mathrm{Mn}_{2} \mathrm{O}_{7}(\mathrm{x}=0 \sim 0.8)$.

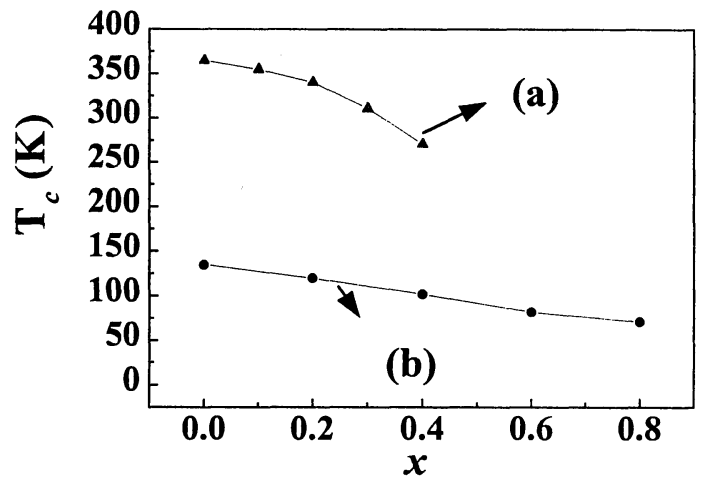

Fig. 4. The transition temperature $\mathrm{T}_{C}$ as a function of $\mathrm{x}$ of (a) $\mathrm{La}_{0.6}\left(\mathrm{Sr}_{0.4-\mathrm{x}} \mathrm{Ca}_{\mathrm{x}}\right) \mathrm{MnO}_{3}$ and (b) $\mathrm{La}_{1.2}\left(\mathrm{Sr}_{1.8-\mathrm{x}} \mathrm{Ca}_{\mathrm{x}}\right) \mathrm{Mn}_{2} \mathrm{O}_{7}$ compounds.

\section{Acknowledgments}

This research is financially supported by National Science Council of the Republic of China under Grant numbers NSC 89-2113-M-002-004 and NSC 89-2113-M-002-030

\section{References}

1) S. Jin, T. H. Tiefel, M. McCormack, R. A. Fastnacht, R. Ramesh and L. H. Chen: Science 264 (1994) 413.

2) C. Zener: Phys. Rev. 82 (1951) 403.

3) P. -G. de Gennes: Phys. Rev. 118 (1960) 141.

4) Z. B. Guo, W.Yang, Y. T. Shen and Y. W. Du: Solid State Commun. 105 (1998) 89.

5) Y. Moritomo, A. Asamitsu, H. Kuwahara and Tokura, Y. Nature 380 (1996) 141.

6) H. Asano, J. Hayakawa and M. Matsui: Phys. Rev. B 57 (1998) 1052.

7) C. H. Shen, R. S. Liu, S. F. Hu, J. G. Lin, C. Y. Huang and S. H. Sheu: J. Appl. Phys. 86 (1999) 2178.

8) C. H. Shen, R. S. Liu, J. G. Lin, C. Y. Huang, J. M. Chen and R. G Liu: to be submitted in (Chem. Mater.). 